\title{
Africana Womanist Perspectives in Reading Dangarembga's Nervous Conditions
}

\author{
Aisha Obaid Al-Harbi \\ Department of European Languages \& Literature \\ King AbdualAziz University \\ Jeddah, Saudi Arabia
}

\begin{abstract}
The aim of this paper is to present a new critical perspective of interpreting and understanding Dangarembga's Nervous Conditions utilizing Africana womanist theory as a viable and practical method of analysis. The study illuminates certain features of Africana Womanism reflected in Nervous Conditions to explore the deep meaning of the African woman experience. Though it is created by an African American intellectual, Hudson-Weems, Africana Womanism transcends the borders of the United States to absorb the needs and aspirations of women from Africa. Reading the novel from the perspective of Africana womanism challenges the view of categorizing Dangarembga as a feminist and her novel in the mainstream of feminist literature on the one hand, and helps to gain more comprehensive understanding of the novel on the other; hence, lies the importance and novelty of the study. To execute this goal, the researcher highlights the most salient attributes of Africana womanism which the female characters in Nervous Conditions fictionally exhibit as: self-namer, self-definer, authentic, complete, and genuine in sisterhood, family centered, male compatible, mothering and nurturing. Utilizing the approach of Africana womanism, all marginalized women should cooperate in creating their own paradigm which stems from their own social reality and reflects their cultural autonomy and integrity.
\end{abstract}

Key words: Africana womanism, African literature, black woman writings, Dangarembga, Nervous Conditions

Cite as: Al-Harbi, A. O. (2017). Africana Womanist Perspectives in Reading Dangarembga's Nervous Conditions. Arab World English Journal for Translation \& Literary Studies, 1(4). DOI: http://dx.doi.org/10.24093/awejtls/vol1no4.9 


\section{Introduction:}

The need to formulate an appropriate black theoretical framework for evaluating African black woman writings is of a paramount significance to many black women intellectuals. To these intellectuals, the interpretation of African literature relying on the Western conceptual framework of feminism entails creating a distorted representation of the African experience and its great cultural heritage. Therefore, it is the role of the black African critic to establish a practical paradigm that reflects the deep and authentic meaning of black culture. Among these critical discourses devoted to the analysis of the struggles, needs and aspirations of people from the African Diaspora is Africana womanism.

The aim of this paper is twofold. One is related to the establishment of the conceptual paradigm of Africana womanism in the investigation and analysis of Dangarembga's Nervous Conditions which delineates female characters who strive to be independent, self-determining and at the same time conscious of their communal function. The other is to contribute to the existing body of knowledge about Dangarembga's work by opening up new practical and authentic avenues of analysis and interpretation. Thus, the significance of this study lies in the intensive need for adopting a new authentic framework that is related to black women since most studies investigating Dangarembga's Nervous Conditions are motivated by feminist concerns which limit the scope of understanding and appreciating the African woman experience. Furthermore, such Eurocentric theories do not reflect the oppression of black women due to racial discrimination. Concentrating on the white middle class woman and her struggle against her male counterpart, feminism disregards issues related to black women or women of color. To correct the deficiency of feminism in encompassing the African woman experience and exploring the needs of black discriminated women, Africana womanism, as this study will prove, lends itself to be an appropriate theory to the examination of black experience in literary texts.

\section{Theoretical Framework:}

Coined in the late 1980s by Clenora Hudson-Weems, Africana womanism represents an ideology which focuses on the experiences, realities, struggles and needs of all Africana women (Ntiri, 2001, p.166). Relying on African cultural roots, Africana womanism is addressed to all black women to empower black people and to establish a kind of familiarity among all Africana women all over the world. In this respect, Kolawole (1997) states that Hudson-Weems' Africana womanism "underscores a closer affinity among all African women globally"(p.25).

Africana womanism decides that Africana women are respectively marginalized due to their race, socio-economic condition and gender. Distinguishing itself from Feminism, Africana womanism operates on the assumption that race is of a paramount importance in any discussion related to black women (Ntiri, 2001, p.164). The racial and gender antagonisms of white women are disdained by black women who reject being inferior to the white race and consider their men as an integral part in their struggle to dismantle the shackles of enslavement, marginalization and poverty. Hence, Feminism is seen as " a separatist and non-inclusive agenda for Africana women" (Ntiri, 2001, p.164).

Africana womanism is developed to defy false and distorted representations of black women by feminist discourse. Hudson-Weems (1993) has rejected feminism and other feminist 
movements for their inadequacy to encompass the African woman experience. She contends that feminism as a Western ideology is inapplicable to the African woman situation. It is incapable of understanding some of the inherent values of African culture which encourages compatibility and congruity between man and woman and enhances the centrality of the family. If Feminism succeeds in solving the problems of the white woman whose suffering is limited to gender oppression, it fails to soothe the African woman who is victimized due to her race and class. In her disdain of applying the western paradigm of feminism to black literary texts, she states: "Feminism, a term conceptualized and adopted by White women, involves an agenda that was designed to meet the needs and demands of that particular group" (1993, p.22). For example, from a feminist point of view, the female characters in Nervous Conditions are oppressed, silenced and invisible due to patriarchal authority. In spite of the fact that they show their antagonism and rebellion against their men, they never become victorious in front of their male counterparts. This feminist perspective, according to some Africana womanists, falls short in absorbing and reflecting the positive and realistic side of African woman reality and experience in the novel.

According to Hudson-Weems,(1993) black feminism originated from western feminism fails to meet the concerns of African women and it "is not a word that describes the plight of Black women" (p.15). Hudson- Weems's dissatisfaction with black feminism is expressed in the following lines:

Black feminism is some Africana women's futile attempt to fit into the constructs of an established White female paradigm. At best, Black feminism may relate to sexual discrimination outside the African community, but cannot claim to resolve the critical problems within it, which are influenced by racism or classism (p.35 ).

In this respect, Bates (2005) resolves that:

Hudson-Weems's term [Africana womanism] is neither a derivative of nor an appendage to African feminism, black feminism, feminism, or Walker's popularly accepted womanism. One difference is that Africana Womanism rejects as foremost in women's struggle gender as an issue and the male as an enemy... and it has no identification with any traditional feminist organizations (p.37).

To identify the essence of Africana womanism, Hudson-Weems (1993) asserts:

Neither an outgrowth nor an addendum to feminism, Africana Womanism is not Black feminism, African feminism, or Walker's womanism that some Africana women have come to embrace. Africana Womanism is an ideology created and designed for all women of African descent. It is grounded in African culture, and therefore, it necessarily focuses on the unique experiences, struggles, needs, and desires of Africana women... . The primary goal of Africana women, then, is to create their own criteria for assessing their realities, both in thought and in action. (pp. 24, 50) 
It is worth mentioning that the majority of Africana intellectuals have rejected to adopt Feminism and the other derivative movements for several reasons: first, they are confused by the racist agenda of Feminism. Secondly, those who adopted Feminism are not relieved from the social, sexual and racial agonies. Thirdly, the black and white women belong two distinct groups with different realities and experiences and it is too difficult to be united by a single frame of thought.

Africana womanism is hailed by the intellectual arena of modern black critics and writers. Zula Sofola, a prominent Nigerian playwright and critic, states in the foreword to Africana Womanism: Reclaiming Ourselves, it is "not simply a scholarly work, one of those in mainstream, but our own. It is a new trail blazed with incontrovertible revelations on the African question and gender question" (quoted in Africana Womanism, 1993, p. xvii). She adds that Africana womanism "confronts the Eurocentric avalanche of works on question of gender" (xvii).

The ardent black woman critic of African descent, Hudson-Weems (1997) believes in the intensive need to create a theoretical framework that unites and empowers black women instead of relying on foreign theories in treating black experiences when she argues:

As we approach the last hour leading up to the next millennium, I cannot stress enough the critical need today for Africana scholars throughout the world to create our own paradigms and theoretical frameworks for assessing our works. We need our own Africana theorists, not scholars who duplicate or use theories created by others in analyzing Africana texts. ( p. 79)

Therefore, she suggests Africana womanism as a conceptual framework which stems from African culture to provide an authentic image of black women as reflected in black literature.

Hudson-Weems distinguishes Africana womanism from other feminist discourses by adopting attributes that define Africana womanism which include: self-naming, self-definition, genuine sisterhood, family-centeredness, in concert with male in struggle, flexible role player, strong, male compatible, wholly recognizable, complete, authenticity, spirituality, respect and appreciation of elders, adaptability, ambition, tendency to mothering, and nurturing. These attributes are reflected in black woman literature. It is through the creativity of a group of woman writers, the world is introduced to the authentic black woman's life and experience. In this respect, Thompson (2001) maintains:

Toni Morrison, Mariamma Ba, Nwapa, Maylor and Dangarembga provide support to one another as audience, fellow artists and critics. These authors demonstrate not only the tenets of African womanism but more significant these texts speak The Soul of African women in their stories. (p.184)

The present study focuses on the most salient attributes of Africana womanism which the female characters in Nervous Conditions fictionally exhibit as : self-namer, self-definer, authentic, complete, genuine in sisterhood, family centered, male compatible, mothering and nurturing. 


\section{Characteristics of Africana womanism in Nervous Conditions:}

Dangarembga's Nervous Conditions (2004) has reflected the destructive impact of colonialism and colonial education on the black individual. European colonialism introduced into Africa a type of education which perpetuated subjugation, underdevelopment and inferiority. European education inculcated into the minds of African students the superiority of the white race and the inferiority of the black. Therefore, in this educational system, African history and tradition were replaced by European culture and values. Consequently, many colonized Africans dissociated themselves from their own cultural roots and became assimilated to western culture (Nwanosike \& Onyije, 2011, p.628). As a committed African writer, Dangarembga has fictionally delineated some Africana womanist characters who strive to correct the distorted selfimage of the African woman to regain self confidence in their past cultural heritage.

\section{A. Africana woman as self-namer, self- definer and authentic:}

Self-naming is one the prominent attributes of Africana womanism. Naming holds a significant role in African culture since " the proper naming of a thing gives it essence" (HudsonWeems, 2004, p.18). Therefore, the appropriate naming in Africana womanism is a prerequisite for the survival of Africana woman. To be appropriate, the Africana womanist's name should be expressive of her identity and cultural reality. Hudson-Weems (1993) maintains that the community of black Americans tend to be distinguished from others "in terms of ... Africana cultural experiences, retaining the African ways in African-American culture"(p.57). Therefore, Africana people usually designate names and nicknames to themselves and to other members in their community. By doing so, they reject the false and distorting labeling of Africana women and men which was once "left in the hands of the dominant group" (p. 2).

In Nervous Conditions, the Shona community consists of complex hierarchal relations which are distinguished by titles. Therefore, characters are given names and titles to indicate respect and status in familial relationship. For example, the title "Baba" in Babamukuru's name shows respect for adult male from the father side. "Tete" is another title of respect given to females from the father's side like Tete Gladys who is the sister of Tambu's father. "Sisi" is a title given to young unmarried females to be distinguished from married ones (Agatucci, 2010). In other words, names and titles mentioned in Nervous Conditions are related to a significant attribute of Africana womanism which is respect for elders. Old people hold a pivotal position in the African community and they are given titles as a means to be distinguished from others, a cultural feature which the Western society neglects.

According to Hudson-Weems (1993), Africana woman should have a name that reflects her authentic personality and identity related to her cultural background. For example, Maiguru is known as Mother. Although she has travelled abroad and is exposed to western culture, she remains faithful and authentic to her traditional role as a mother. Being an Africana woman, she does not give up her title as a mother who takes care not only of her children but also the children of her relatives like Tambu and Nhmo.

Self-naming and self-definition are two deeply connected characteristics in creating the identity of Africana womanism. The Africana womanist is conscious enough to create her identity in accordance with her cultural reality. In this respect, Hudson-Weems (1993) claims: 
From a historical perspective, the Africana woman has always managed to eke' out a separate, private reality for herself and her family, regardless of that defined by the slave master, for example. A close look at John Blassingame's Slave Community revealsmuch evidence that the slaves, women included, as Africana women's activities have always been by and large collective, defined themselves and their community in terms of their African cultural experiences, retaining the African ways in African-American culture. (p. 57)

Nyasha and Tambu are two female characters who are exposed to Western culture through colonial education. Both of them suffer from the destructive impact of colonial educational system, however, they resist being defined by Euro-centric standards. Instead, they create for themselves a reality compatible with their African culture. Realizing the evil method of brainwashing implemented in the colonizer's teachings to inculcate the inferiority and subjugation of the black race, Nyasha resolves:

Their history. ... liars. Their bloody lies . . . They've trapped us. They've trapped us. But I won't be trapped. I'm not a good girl. I won't be trapped.' 'I don't hate you, Daddy,' she said softly. 'They want me to, but I won't.' 'Look what they've done to us,' she said softly. 'I'm not one of them, but I'm not one of you' (Dangarembga, 2004, p. 205).

In the above mentioned lines, Nyasha highlights the negative state of fragmentation that her generation of young educated Africans suffered from due to their exposure to Western education. Successfully, Nyasha confronts her mental nervous condition through giving up the values of European culture and adopting the values of her African ancestors. Commenting on Nyasha's process of self-definition, Thompson (2001) encapsulates:

Thus, Nyasha, a product of the new generation of educated Africans, with her exposure to British schooling and culture, nevertheless comes to appreciate tradition and questions the value of taking on the entire culture of colonialism and modernity. Nyasha demonstrates the inability of Eurocentric culture to embrace the needs of African women in adolescence or at any level of maturity. (p.182)

To crown it all, she decides to get rid of all the books about European culture and to replace them with those of traditional African culture. She seeks enjoyment in crafting African art and molding clay pots.

Similarly, Tambu seeks to define herself according to her native culture. In her journey of self-definition, she admitted "I was always aware of my surroundings" (Dangarembga, 2004, p. 112). She rejects western philosophy and realizes: "I can no longer accept Sacred Heart [her colonial school] and what it represented as the sunrise on my horizon" (Dangarembga, 2004, p.208). Adopting the cultural heritage of their forefathers, Nyasha and Tambu manifest authenticity to their African roots. In Africana womanism, wholeness is defined as "completeness", while authenticity is defined as one's ability to be "culturally connected" (Hudson-Weems, 1993, p. 69). Faithfully embracing their culture, they achieve the state of wholeness and completeness that the fragmented souls of assimilated young Africans lack. In 
other words, Tambu and Nyasha are two Africana womanists who represent these attributes of Africana womanism.

\section{B. Africana woman as genuine in sisterhood:}

The Africana womanist is capable of establishing genuine sisterhood. Hudson-Weems (1993) defines this attribute as follows:

This sisterly bond is a reciprocal one, one in which each gives and receives equally. In this community of women, all reach out in support of each other, demonstrating a tremendous sense of responsibility for each other by looking out for one another. They are joined emotionally, as they embody empathetic understanding of each other's shared experiences. Everything is given out of love, criticism included, and in the end, the sharing of the common and individual experiences and ideas yields rewards (p. 65).

This characteristic of genuine sisterhood is fictionally represented throughout Nervous Conditions in the solidarity displayed by all the female characters. In discussing Lucia's problem with her husband, Takesure, "fierce sisterly solidarity ... [was] established in the kitchen"( Dangarembga, 2004, p.140) among all the women of the family to support Lucia. They agree to defend Lucia's issue against the false claims of Takesure .

The intimate relationship between Tambu and Nyasha is reciprocal and rewarding. The two cousins exchange feelings of love and compassion to develop a strong friendship. Contemplating on her relationship with Nyasha, Tambu says:

Looking back, I see that is how our friendship began. In fact, it was more like a friendship that developed between Nyasha and myself. The conversation that followed was a long, involved conversation that young girls have with their best friends, that lovers have under the influence of the novelty and uniqueness of their love, the kind of conversation that cousins have when they realize that they like each other in spite of not wanting to (Dangarembga, 2004, p.79).

Tambu shows deep concern and care for her cousin Nyasha who has a strained relationship with her father. She affirms that, "I was more concerned about Nyasha, because Babamukuru had Maiguru to look after him and the solace of knowing Nyasha was wrong"(Dangarembga, 2004, p.120). However, Tambu finds no fault in criticizing Nyaha's disrespect for her parents and realizes that it is her duty to advise and guide her claiming "Even if you have been to England you should respect your mom; ... I wouldn't speak to my mom the way I have heard you speak to Maiguru" ( Dangarembga, 2004, p.79). It is worth noting that respect for elders is an integral value in African culture and the Africana womanist Tambu tries to remind her westernized cousin of the values of their great cultural heritage.

On the other hand, it is out of sheer sisterhood, Nyasha has done her best to show Tambu the negative side of colonial education. She warns her against the "dangers of assuming that Christian ways are progressive ways" (Dangarembga, 2004, p.150). She explains to her how colonial education supported by Christianity helps in physically and spiritually deteriorating the African culture and its people. She demonstrates that salvation is attained through going back to 
old ways of the ancestors. Therefore, she appreciates and encourages the traditional cleansings ceremony of Tambu's parents which Tambu herself disapproves.

As Africana womanists, Nyasha and Tambu never secede demonstrating their genuine sisterhood throughout the novel. When Babamukuru decides that Tambu's parents should have a wedding ceremony to cleanse their sins, Tambu refuses to attend exposing her dissatisfaction with the shame that the ceremony might bring to her parents. As a result, Babamukuru punishes Tambu for her disobedience. He decides Tambu should be given fifteen lashes in addition to taking all the responsibilities of the household with nobody to help her. Despite her father's warning, Nyasha decides to take the risk and help Tambu in the household. Expressing her gratitude to her sincere cousin, Tambu resonates:

She was terribly angry about the severity of my punishment and was all for asking Babamukuru whether he intended to educate me or kill me. She insisted she would help me in spite of the fact that help had been forbidden, and she would have done it too. She would have been up at four o'clock to help me clean the living-room and prepare breakfast. Or else she would have cooked the afternoon meal while I did the cleaning ...She would have done all this for me if I had let her, but I was so frightened of Babamukuru now and my own daring in having defied him once that I begged her not to, and when she saw how upset I was, she agreed not to help (Dangarembga, 2004, p.171).

\section{Africana woman as family centered, male compatible, mothering and nurturing:}

In African culture, family is the basic unit of society. It is not confined to the husband, his wife and their children but it is extended to encompass other people of the clan. Mbiti (1969) resolves that:

for African people the family has a much wider circle of members than the word suggests in Europe or North America. In traditional society, the family includes children, parents, grandparents, uncles, aunts, brothers and sisters who may have their own children and other immediate relatives... in traditional life, the individual does not and cannot exist alone except corporately. He owes his existence to other people... Only in terms of other people does the individual becomes [sic] conscious of his own being, his own duties, his privileges and responsibilities towards himself and towards other people. (pp.106-8)

In Nervous Conditions, Dangarembga has fictionally presented the centrality of the family in African life. In African culture, the individual should be in the service of his community. Conscious of his role as the son of his people, Babamukuru realizes that his academic degree belongs to them. He feels responsible for caring and providing for all the members of his clan. Working as the Headmaster, he has done his best to avail educational opportunities to his people. Therefore, his coming back from abroad is a celebration that all members of his community participate in with joy and pride. Describing the celebration of Babamukuru's return, Tambu recounts: 
Slowly the cavalcade progressed towards the yard, which by now was full of rejoicing relatives. The cars rolled to a stop beneath the mango trees . . Babamukuru stepped out of his car, paused behind its open door, removed his hat to smile graciously, joyfully, at us all ...The next minute he was drowned in a sea of bodies belonging to uncles, aunts and nephews; grandmothers, grandfathers and nieces; brothers and sisters of the womb and not of the womb. The clan had gathered to welcome its returning hero. (Dangarembga, 2004, p. 36)

Shedding light on the strong correlation among Africana womanist's attributes of familycenteredness, compatibility with her man and mothering, Hudson-Weems (2008) elucidates "The Africana womanist insisted on identifying herself as mother and companion. ... The Africana womanist is family-centered, as she is more concerned with her entire family rather than with just herself and her sisters" (pp.58-65). Distinguished from white women who, as HudsonWeems announces, "seek to replicate the individualism of White patriarchal capitalism" (p.58), Africana womanists pursue motherhood. In Nervous Conditions, one of the Africana womanist characters that practically manifests these attributes of family centeredness, male compatibility, mothering and nurturing is Maiguru, Babamukuru's wife. Maiguru provides her love, care and attention to her husband and children. Realizing the importance of the family, she does not hesitate to participate with her husband in supporting his relatives financially. Having a Master degree, Maiguru does not give up her traditional responsibility and help other women in preparing food for her husband's relatives. During holidays, she shows sincere care and attention and works diligently with other women to ensure the happiness and satisfaction of all members of the family. Consequently, Maiguru aims to be "liberated to the community, family and its responsibilities" (Hudson-Weems, 1993, p. 34).

Hudson-Weems (2004) explicates, "[t]he Africana womanist... perceives herself as the companion to the Africana man and works diligently toward continuing their established union" (p. 29). Maiguru aspires to have a strong companionship with her husband because she realizes that having mutual love and respect with her husband is the essential element of building a healthy family as Hudson-Weems (2004) decides on the relationship between men and women, "We must understand that we. . . are in this together. We need to recognize that we are each other's better half, and that we need each other in order to work through this crisis" ( p. 96).

Maiguru, Nyasha's and Chido's mother, represents the ultimate image of Africana mother and nurture. She constantly provides her love and concern to her children and all children of her community. Tambu recounts how she is sweetly welcomed and well treated by Maiguru when she arrived at the mission. Being a nurture, "My Maiguru was concerned about everyone, she was gentle, conscientious" (Dangarembga, 2004, p.79), Tambu resolves. One of the clearest examples that shows Maiguru's nurturing character is expressed in the following lines:

Somehow the question of tuck had escaped Maiguru's maternal attention and although I insisted to her that I did not need chocolate biscuits and potato crisps and orange juice, she insisted that I did, and so we stopped in town to buy these things... Maiguru bought enough tuck to feed a small colony for several months... we piled the packets and bottles and tins into the car. There was jam, tomato sauce, all sorts of things besides the 
biscuits and squash and crisps. Then, just as Babamukuru started the engine, Maiguru remembered that I would need a tumbler to drink my orange juice out of and went back to buy it. (Dangarembga, 2004, pp. 195-6)

\section{Conclusion:}

In brief, Nervous Conditions demonstrates some characteristics of Africana womanism. Nyasha and Tambu are two female characters whose names and identities are drawn from their realities as Africana women. They realize that by adopting their Africana names, they reject the improper and distorted labeling of the colonizer. Their constant strive to define themselves according to their cultural realities makes them authentic and whole, which are two attributes of Africana womanism. Their deep love and concern for each other stress their genuine sisterhood, another characteristic of Africana womanism. Furthermore, African woman in Nervous Conditions is not victimized by her male counterpart, but she is aware of her role as a crucial partner and compatible to her man in constructing their life as reflected in the character of Maiguru. She recognizes the futility of fighting her man to have a voice because her identity as a functional mother and nurture to her family and community is well established.

In addition, this study recommends that this cultural awareness of womanism should not be confined to Africana women. Muslim and Arab women should strive to attain their cultural autonomy instead of blindly imitating other foreign agenda. Utilizing the approach of Africana womanism, Muslim and Arab women should cooperate in creating their own paradigm which stems from their own social reality and reflect their cultural autonomy and integrity.

\section{About the Author: \\ Dr. Aisha Obaid Al-Harbi is Assistant Professor of English Literature in the Department of European Languages and Literature at King Abdul-Aziz University, Saudi Arabia. Her research interests include African Literature, African American Women Writings, American Literature and Post-colonial Studies.}

\section{References:}

Agatucci, C. (2010). Tsitsi Dangarembga \& Nervous Conditions. African Authors. Retrieved from http://web.cocc.edu/cagatucci/classes/hum211/dangarembga.htm.

Bates, G. (2005). Alice Walker: A Critical Companion. Westport: Greenwood Publishing Group. Dangarembga, T. (2004). Nervous Conditions. (2nd ed.) U.K.: Ayebia Clarke Pub.

Hudson-Weems, C.(1997). Africana Womanism and the Critical Need for Africana Theory and Thought. The Western Journal of Black Studies, 21(2), 79-84.

Hudson-Weems, C. (2004). Africana Womanist Literary Theory. New Jersey: Africa World Press.

Hudson-Weems, C. (2008). Africana Womanism \& Race \& Gender in the Presidential Candidacy of Barack Obama. Bloomington, IN: Author House.

Hudson-Weems, C. (1993). Africana Womanism: Reclaiming Ourselves. Troy, Michigan: Bedford Publishers, Inc. 
AWEJ for translation \& Literary Studies Volume, 1 Number 4, October 2017

Kolawole, M. E. M. (1997). Womanism and African Consciousness. Trenton, N.J: Africa World Press.

Mbiti, J. (1969). African religions and philosophy. London: Heinemann Educational Books, Ltd.

Nwanosike, O. F \& Onyije, L. E. (2011). Colonialism and education. Mediterranean Journal of Social Sciences, 2 (4), 41-47.

Ntiri, D.W. (2001). Reassessing Africana womanism: continuity and change. The Western Journal of Black Studies, 25 (3), 163-7.

Thompson, T. B. (2001). Common Bonds from Africa to the U.S.: Africana Womanist Literary Analysis. The Western Journal of Black Studies, 25 (3), 177-84. 